\title{
Radiological Mapping of AI-Dabaa Site at Low Depth Profile for Evaluation its Suitability for Disposal of Radioactive Wastes
}

\author{
M. Badraway ${ }^{1}$, Abdalla Osman ${ }^{2}$ and Sayed A. El-Mongy ${ }^{3}$ \\ ${ }^{1}$ Armed Forces of Egypt. \\ ${ }^{2}$ Cairo University, Faculty of Science, Physics Dept. \\ ${ }^{3}$ Egypt Nuclear Regulatory Authority (ENRRA).
}

\begin{abstract}
Disposal sites use series of natural and engineered barriers to contain either radioactive wastes and or spent nuclear fuel. Migration of radionuclide and their pathways studies are carried out as selection criteria of radioactive waste disposal/storage facility. In the framework of the planned NPPs program at Al-Dabaa site, radiological mapping at low depth profile of a specific area within the site has been carried out for evaluation its suitability for disposal of radioactive wastes. Twenty samples were collected from different bore holes of about 12-meterdepthprofile.The samples were transported to the laboratory and prepared for non-destructive assay using well calibrated $60 \%$ efficiency High-Purity Germanium $(\mathrm{HpGe})$ detector. The natural radioactivity of ${ }^{235} \mathrm{U},{ }^{238} \mathrm{U}\left({ }^{234} \mathrm{Th}\right),{ }^{226} \mathrm{Ra},{ }^{232} \mathrm{Th}$ and ${ }^{40} \mathrm{~K}$ were determined and quantified. The ${ }^{235} \mathrm{U} /{ }^{238} \mathrm{U}$ activity ratios were also calculated and found to be within the natural signature. The Absorbed dose rates ( $\mathrm{nGy} / \mathrm{h}$ ) were also calculated and found in the average world value; $59 \mathrm{nGy} / \mathrm{h}$. The man-made ${ }^{137} \mathrm{Cs}$ was also found in ultra-low activity concentrations, where the highest value was found to be $0.00987 \mathrm{~Bq} / \mathrm{kg}$. The mineralogy of the collected site samples was also investigated by $x$-ray diffraction (XRD) analysis technique to identify and determine the major mineral structure of the samples. It was observed that Dolomite and Calcite are the major minerals of the investigated site. The results are discussed and represented as histograms, contour mapping and 3D correlations. These results are also going to be used as inputs and bases for a future work; code modeling for evaluation of Al-Dabaa site.
\end{abstract}

Keyword: Radiological mapping/Al-Dabaa site/HpGe/XRD/Radioactive wastes/ Absorbed dose rate Language: English

Date of Publication: $30-06-2018$

DOI: $10.24297 /$ jap.v14i2.7449

ISSN: 2347-3487

Volume: 14 Issue: 2

Journal: Journal of Advances in Physics

Website: https://cirworld.com

This work is licensed under a Creative Commons Attribution 4.0 International License. 


\section{INTRODUCTION}

The disposal of long-lived radioactive wastes by deep burial in suitable rock formations is an emotive issue. Although, disposal of wastes is technically not exceptionally demanding, the demonstration of long- term safety using predictive hydrogeological and geochemical models. In order to validate the results of such predictions, the models and associated computer codes and databases must be tested and calibrated on natural radioactive systems (1). It looks at how information on natural radiation sources, and the distribution and behavior of radionuclides in geochemical systems (1).To predict transport and radionuclides retardation in soil, it is essential to understand the physical and chemical phenomena involved. Experiments dedicated to understanding radionuclide behavior in the material environment must be described mainly for lake sediments and rocks as carried out in recent work $(2,3)$. The primary goal of the disposal of radioactive waste is the protection of people and the environment in the long term, after the disposal facility has been closed. In this period, migration of radionuclides to the accessible biosphere, dispersion of radionuclides into the accessible biosphere and the consequent exposure of people may occur. This is a consequence of the slow degradation of engineered components and the slow transport of radionuclides from the facilityby natural processes. Discrete events may lead to an earlier or greater release. Such events could be of either natural or human origin(4).The natural radioactivity covers up to $75 \%$ of the total radioactivity in the world and has its origins in the interaction of terrestrial elements with high energy cosmic rays (cosmogenic radionuclides) or in the existing materials on Earth since its formation (primordial radionuclides). In this regard, there are differences in the levels of radioactivity throughout the Earth's crust.For example, India and mountains like the Alps are among the areas with the highest level of natural radioactivity due to their composition of rocks and sand(5). The most frequent radionuclides in soils are naturally radium-226 $\left({ }^{226} \mathrm{Ra}\right)$, radon $222\left({ }^{222} \mathrm{Rn}\right)$, thorium$232\left({ }^{232} \mathrm{Th}\right)$, uranium-238 $\left({ }^{238} \mathrm{U}\right)$ and potassium $-40\left({ }^{40} \mathrm{~K}\right)(5,6)$.

Generally, radioactive wastes can be disposed at either shallow or deep based on its radiation level and type of radionuclides; low, medium and high level rad-wastes. Characterization of any site for radioactive waste disposal needs comprehensive studies in the field of Geological, Geophysical, Hydrogeology and Lithology $(7,8)$.

This study objective is evaluation of natural and artificial radionuclides level and mineralogy of Al-Dabaa site at low deep profile as parameters for evaluation its suitability for future disposal of radioactive wastes.

\section{METHODS AND ANALYSIS}

\section{a) Sample Collections and Preparation:}

Sensitive and efficient GPS was used to describe the samples location coordinates. The samples lie between longitudes $\left(28^{\circ} 27^{\prime}-28^{\circ} 35^{\prime}\right)$ E, Alexandria - Matruh highway and latitudes $\left(31^{\circ} 02^{\prime}-31^{\circ} 05^{\prime}\right) \mathrm{N}$. The 20 samples were collected from boreholes of $\sim 12$-meter depth of specific area at Al-Dabaa site Fig.(1).The samples are collected from a grid of about $1.0 \mathrm{~km}$ long and $0.5 \mathrm{~km}$ width within al Dabaa site, which is the potential/probable location of the NPP and its spent fuel storage facility. The masses of the collected samples are $360 \mathrm{~g}$. The samples were transported to the main radiation laboratories of the Egyptian armed forces at Cairo- Ismailia $4.5 \mathrm{~km}$. The samples were dried at $100{ }^{\circ} \mathrm{C}$ for $48 \mathrm{~h}$ to ensure that moisture is completely removed, ground, crushed to fine grain size of about 100 meshes to small pieces and then sieved in order to be homogenized. The samples were then packed in containers and sealed for about 4 weeks in order to ensure that the daughter products of ${ }^{226} \mathrm{Ra}$ and ${ }^{232} \mathrm{Th}$ are in secular equilibrium with their respective parent radionuclides $(9,10)$. 


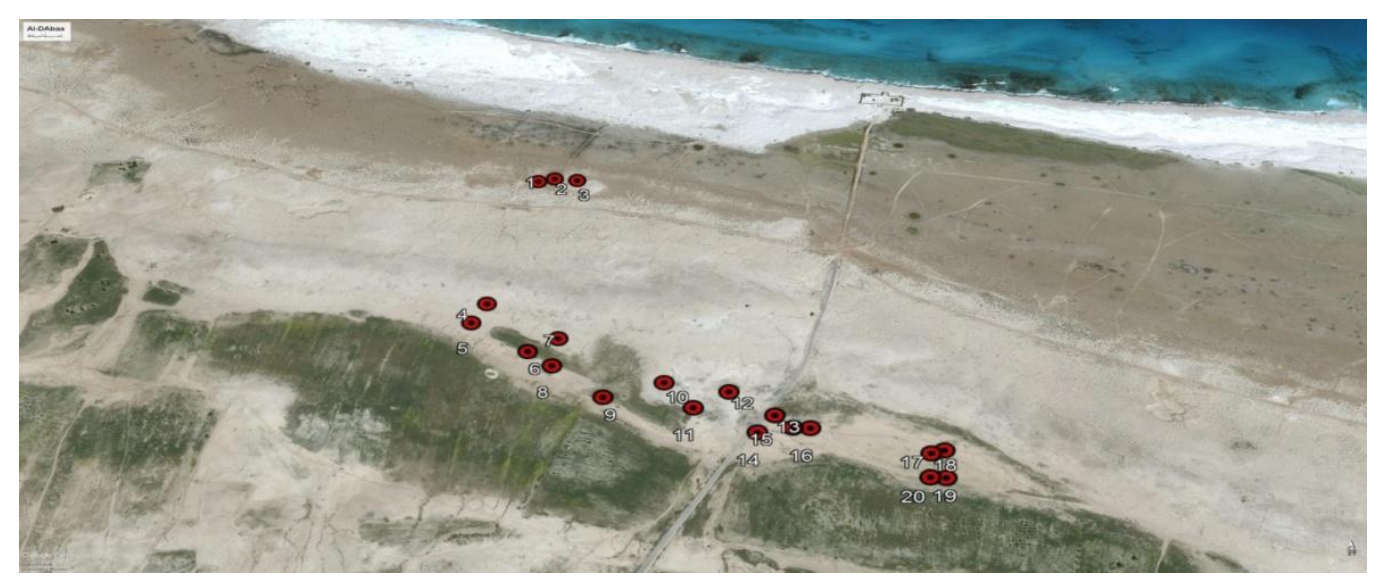

Fig. (1): Locations of the collected samples fromAl-Dabaa Site.

\section{b) Radioactivity Measurements:}

The gamma spectrometer used is based on High-Purity Germanium ( $\mathrm{HpGe})$. It is coaxial detector- Model No.GMX60P4-83-CW with its electronics. The relative efficiency of the detector at $1.33 \mathrm{MeV}$ of Cobalt-60 $\left({ }^{60} \mathrm{Co}\right)$ is $60 \%$ warranted (62\% Measured). It's Resolution (FWHM) at $1.33 \mathrm{MeV}$ is $2.3 \mathrm{keV}$ warranted (2.2keV Measured) at recommended operating bias of negative 3000Volts. The Peak to Compton Ratio is 56:1 warranted (62:1 Measured).Both energy and efficiency calibration were carried out using standard ${ }^{226} \mathrm{Ra},{ }^{137} \mathrm{Cs}$ and ${ }^{60} \mathrm{CO}$ sources. Different reference IAEA materials were used for activity calculations and as quality control indicators.

\section{c) X-Ray Diffraction Analysis (XRD) :}

The samples were analyzed using non-destructive XRD analysis(Model X Pert PRO-Netherlands).It contains 60 KV high tension generator, a ceramic diffraction x-ray tube type PW 3373 mounted onto the Goniometer in a tube shield and a detector to measure the intensity of the diffracted $x$-ray beam of type PW 3011/20 proportional counter. The minerals texture and type is mainly calculated using the following Bragg's law equation (9):

$$
\mathrm{n} \lambda=2 \mathrm{~d} \operatorname{Sin} \theta
$$

Where $\lambda$ is the incident $x$-ray wavelength, $d$ is the distance (spacing) between crystal layers and $\theta$ is the angle of incident $x$-ray.

\section{RESULTS and DISCUSSIONS}

The activity concentrations of the collected twenty samples at $\sim 12 \mathrm{~m}$ depth were calculated by using the following equation (10):

$$
\mathrm{A}=\frac{\mathrm{C}_{\text {net }}}{\varepsilon_{\mathrm{abs}} \cdot \mathrm{I}_{\gamma}\left(\mathrm{E}_{\gamma}\right) \cdot \mathrm{t} \cdot \mathrm{m}}
$$

Where, $C_{n e t}$ is the net number of counts in a given peak area without background contribution. $A$ is the specific activity $(\mathrm{Bq} / \mathrm{kg}), \mathrm{m}$ is the mass of the measured sample $(\mathrm{Kg}), \varepsilon_{\mathrm{abs}}$ is the detector efficiency, $\mathrm{I} \gamma$ is the branching ratio for specific energy and $\mathbf{t} . \mathrm{m}$ is the measured time in second (10).

The absorbed Dose Rate ( $D_{\text {- in }} \mathrm{nGy} / \mathrm{h}$ ), in the air at $1 \mathrm{~m}$ above the ground level, was estimated using the following equation( 11):

$$
\mathrm{D}=0.461 \mathrm{~A}_{(\mathrm{Ra})}+0.623 \mathrm{~A}_{(\mathrm{Th})}+0.0414 \mathrm{~A}_{(\mathrm{K})}
$$


Where: $A_{(\mathrm{Ra})}, \mathrm{A}_{(\mathrm{Th})}$ and $\mathrm{A}_{(\mathrm{K})}$ are the average activity concentrations of ${ }^{226} \mathrm{Ra},{ }^{232} \mathrm{Th}$ and ${ }^{40} \mathrm{~K}$ in $\mathrm{Bq} / \mathrm{kg}$ respectively in the measured samples. For this formula, it is assumed that all the decay products of ${ }^{226} \mathrm{Ra}$ and ${ }^{232} \mathrm{Th}$ are in equilibrium with their daughters. Also, since ${ }^{226} \mathrm{Ra}$ is contributed for the total dose by about $98 \%$ so it is replaced by ${ }^{238} \mathrm{U}$ in this formula and therefore there is no difference if there is equilibrium between ${ }^{238} \mathrm{U}$ and ${ }^{226}$ Ra or not $(\mathbf{1 1}, \mathbf{1 2})$.

The average world values of natural radioactivity in soil are $35 \mathrm{~Bq} / \mathrm{kg}$ for ${ }^{238} \mathrm{U}$ series, $30 \mathrm{~Bq} / \mathrm{kg}$ for ${ }^{232} \mathrm{Th}$ seriesand $400 \mathrm{~Bq} / \mathrm{kg}$ for ${ }^{40} \mathrm{~K}$. It is $59 \mathrm{nGy} / \mathrm{h}$ for the average absorbed dose rate (11).

The results of the experimental natural and artificial radioactivity analyses and calculations are given in the following tables (table 2), histograms, contour and 3Dcorrelations.

Table 2: Level of Radioactivity, ${ }^{235} \mathrm{U} /{ }^{238} \mathrm{U}$ Activity Ratio, ${ }^{137} \mathrm{Cs}$ and Dose Rate of Al-Dabaa Site.

\begin{tabular}{|c|c|c|c|c|c|c|c|c|}
\hline $\begin{array}{c}\text { Sampl } \\
\text { e }\end{array}$ & ${ }^{235} \mathrm{U}$ & ${ }^{234} \mathrm{Th}$ & ${ }^{226} \mathrm{Ra}$ & ${ }^{40} \mathrm{~K}$ & ${ }^{232} \mathrm{Th}$ & $D(n G y / h)$ & ${ }^{235} U^{/ 238} U$ & ${ }^{137}$ Cs \\
\hline 1 & $3.2158 \mathrm{E}+00$ & $7.9021 E+01$ & $6.6821 E+01$ & $1.7609 \mathrm{E}+01$ & $2.1360 \mathrm{E}+00$ & $3.29 E+01$ & 0.0406 & $\begin{array}{c}1.3966 \mathrm{E}- \\
02\end{array}$ \\
\hline 2 & $1.8761 \mathrm{E}+00$ & $4.5053 \mathrm{E}+01$ & $3.9643 \mathrm{E}+01$ & $8.0515 E+01$ & $5.4297 \mathrm{E}+00$ & $2.50 \mathrm{E}+01$ & 0.0416 & $\begin{array}{c}1.0906 \mathrm{E}- \\
02\end{array}$ \\
\hline 3 & $2.1499 \mathrm{E}+00$ & $5.2586 \mathrm{E}+01$ & $4.4073 E+01$ & $1.4918 \mathrm{E}+01$ & $1.5506 \mathrm{E}+00$ & $2.19 E+01$ & 0.0408 & $\begin{array}{c}1.8709 \mathrm{E}- \\
02\end{array}$ \\
\hline 4 & $1.9951 E+00$ & $4.5477 \mathrm{E}+01$ & $4.1623 E+01$ & $4.7476 \mathrm{E}+01$ & $4.5755 E+00$ & $2.40 \mathrm{E}+01$ & 0.0438 & $\begin{array}{c}1.5195 \mathrm{E}- \\
02\end{array}$ \\
\hline 5 & $2.1137 E+00$ & $5.1520 \mathrm{E}+01$ & $4.7119 E+01$ & $9.2995 E+01$ & $7.0214 \mathrm{E}+00$ & $2.99 \mathrm{E}+01$ & 0.0410 & $\begin{array}{c}1.8142 \mathrm{E}- \\
01\end{array}$ \\
\hline 6 & $1.2185 \mathrm{E}+00$ & $2.9124 \mathrm{E}+01$ & $2.7973 E+01$ & $3.1380 E+01$ & $1.7639 \mathrm{E}+00$ & $1.53 \mathrm{E}+01$ & 0.0418 & $\begin{array}{c}1.7806 \mathrm{E}- \\
02\end{array}$ \\
\hline 7 & $1.2053 \mathrm{E}+00$ & $3.0102 E+01$ & $2.6587 \mathrm{E}+01$ & $2.1304 E+02$ & $1.4281 \mathrm{E}+00$ & $2.20 \mathrm{E}+01$ & 0.0400 & $\begin{array}{c}1.8345 \mathrm{E}- \\
02\end{array}$ \\
\hline 8 & $1.3182 \mathrm{E}+00$ & $3.2147 \mathrm{E}+01$ & $2.8652 \mathrm{E}+01$ & $6.1512 \mathrm{E}+01$ & $6.2272 \mathrm{E}+00$ & $1.96 \mathrm{E}+01$ & 0.0410 & $\begin{array}{c}1.9008 \mathrm{E}- \\
02\end{array}$ \\
\hline 9 & $1.4285 \mathrm{E}+00$ & $3.4861 E+01$ & $3.1556 \mathrm{E}+01$ & $1.9900 \mathrm{E}+01$ & $2.2984 \mathrm{E}+00$ & $1.68 \mathrm{E}+01$ & 0.0409 & $\begin{array}{c}1.5016 \mathrm{E}- \\
01\end{array}$ \\
\hline 10 & $1.4288 \mathrm{E}+00$ & $3.3668 \mathrm{E}+01$ & $3.1135 E+00$ & $1.6665 \mathrm{E}+02$ & $1.1052 \mathrm{E}+00$ & $9.02 \mathrm{E}+00$ & 0.0424 & $\begin{array}{c}1.3241 \mathrm{E}- \\
02\end{array}$ \\
\hline 11 & $1.0121 \mathrm{E}+00$ & $2.5212 \mathrm{E}+01$ & $2.4679 E+01$ & $3.3501 E+01$ & $3.8561 E+00$ & $1.52 \mathrm{E}+01$ & 0.0401 & $\begin{array}{c}1.9082 \mathrm{E}- \\
01\end{array}$ \\
\hline 12 & $2.6450 \mathrm{E}+00$ & $6.1313 E+01$ & $5.5881 \mathrm{E}+01$ & $6.5526 \mathrm{E}+01$ & $4.2273 \mathrm{E}+00$ & $3.11 E+01$ & 0.0431 & $\begin{array}{c}1.5735 \mathrm{E}- \\
02\end{array}$ \\
\hline 13 & $3.5241 E+00$ & $8.3459 \mathrm{E}+01$ & $7.1860 \mathrm{E}+01$ & $1.0750 \mathrm{E}+01$ & $5.1370 \mathrm{E}+00$ & $3.68 \mathrm{E}+01$ & 0.0422 & $9.8666 \mathrm{E}-$ \\
\hline
\end{tabular}




\begin{tabular}{|c|c|c|c|c|c|c|c|c|}
\hline & & & & & & & & 03 \\
\hline 14 & $1.2314 \mathrm{E}+00$ & $2.5028 \mathrm{E}+01$ & $2.5962 \mathrm{E}+01$ & $5.1866 \mathrm{E}+01$ & $3.2890 \mathrm{E}+00$ & $1.62 \mathrm{E}+01$ & 0.0492 & $\begin{array}{c}1.9694 \mathrm{E}- \\
02\end{array}$ \\
\hline 15 & $4.5862 \mathrm{E}+00$ & $9.6121 \mathrm{E}+01$ & $9.9879 E+01$ & $1.4841 \mathrm{E}+01$ & $1.2673 \mathrm{E}+00$ & $4.74 \mathrm{E}+01$ & 0.0477 & $\begin{array}{c}1.6201 \mathrm{E}- \\
02\end{array}$ \\
\hline 16 & $1.9516 \mathrm{E}+00$ & $3.9951 \mathrm{E}+01$ & $4.2522 \mathrm{E}+01$ & $2.8661 \mathrm{E}+01$ & $3.5382 E+00$ & $2.30 \mathrm{E}+01$ & 0.0488 & $\begin{array}{c}1.5571 \mathrm{E}- \\
03\end{array}$ \\
\hline 17 & $0.7812 \mathrm{E}+00$ & $1.6960 \mathrm{E}+01$ & $1.7743 E+01$ & $8.4136 \mathrm{E}+01$ & $5.3833 E+00$ & $1.50 \mathrm{E}+01$ & 0.0460 & $\begin{array}{c}1.5759 \mathrm{E}- \\
02\end{array}$ \\
\hline 18 & $2.7622 \mathrm{E}+00$ & $5.6716 \mathrm{E}+01$ & $6.8558 \mathrm{E}+01$ & $5.0233 \mathrm{E}+01$ & $6.0469 \mathrm{E}+00$ & $3.75 E+01$ & 0.0487 & $\begin{array}{c}5.5526 \mathrm{E}- \\
03\end{array}$ \\
\hline 19 & $3.0368 \mathrm{E}+00$ & $6.3603 E+01$ & $6.6989 E+01$ & $3.9827 E+01$ & $4.9703 E+00$ & $3.56 \mathrm{E}+01$ & 0.0474 & $\begin{array}{c}1.0154 \mathrm{E}- \\
02\end{array}$ \\
\hline 20 & $3.3121 \mathrm{E}+00$ & $8.0122 \mathrm{E}+01$ & $7.1254 \mathrm{E}+01$ & $7.0442 E+00$ & $4.3680 \mathrm{E}+00$ & $3.59 E+01$ & 0.0413 & $\begin{array}{c}1.8312 \mathrm{E}- \\
02\end{array}$ \\
\hline
\end{tabular}

It is observed that the highest ${ }^{235} \mathrm{U}$ activity is $4.586 \mathrm{~Bq} / \mathrm{kg}$ for the location No. 15 . While, the lowest value is $0.781 \mathrm{~Bq} / \mathrm{kg}$ for the location No.17 (Fig.2).This is mainly due to mineralogy structure of the samples.

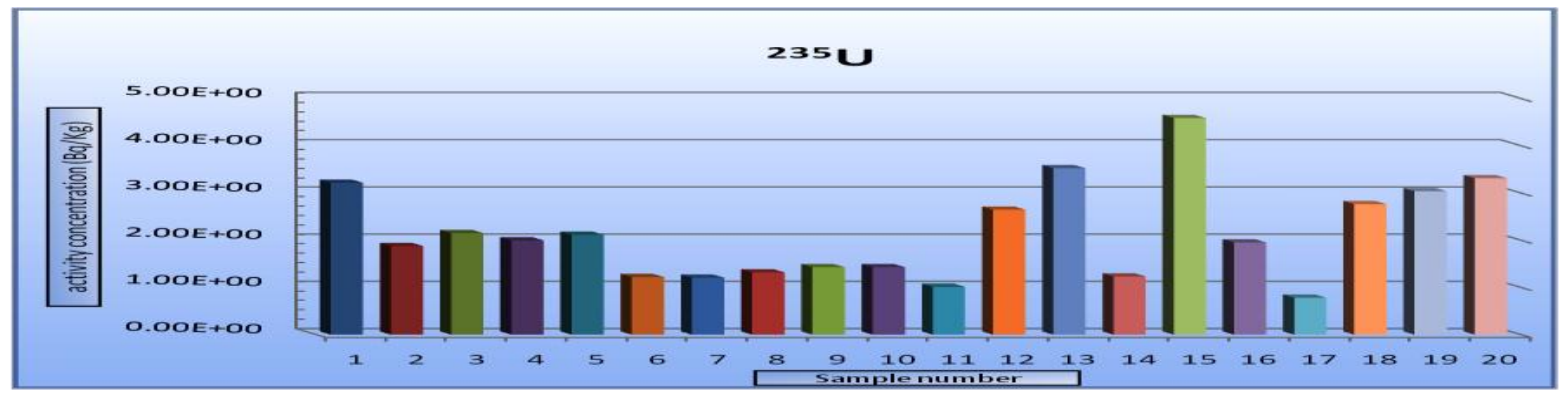

Fig.(2): The measured ${ }^{235} U$ in the studied site samples.

It is observed that the highest ${ }^{238} \mathrm{U}\left({ }^{234} \mathrm{Th}\right)$ activity belongs to the location No. 15 of $\sim 96 \mathrm{~Bq} / \mathrm{kg}$ (Fig.3).

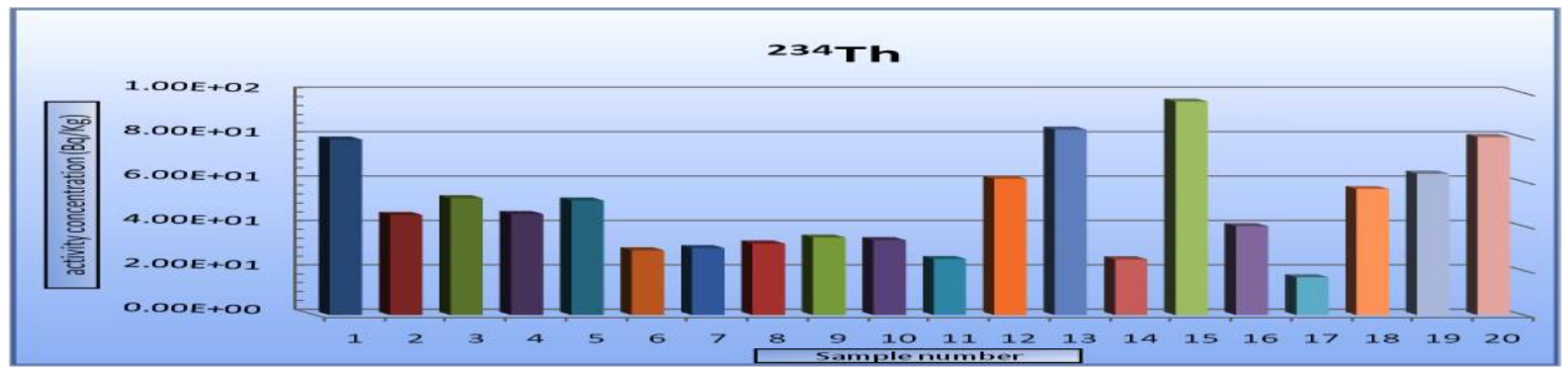

Fig.(3): The measured ${ }^{234} \mathrm{Th}\left({ }^{238} \mathrm{U}\right)$ in the analyzed site samples.

The contour mapping of the site for the area of the collected samples is given in (fig.4). 


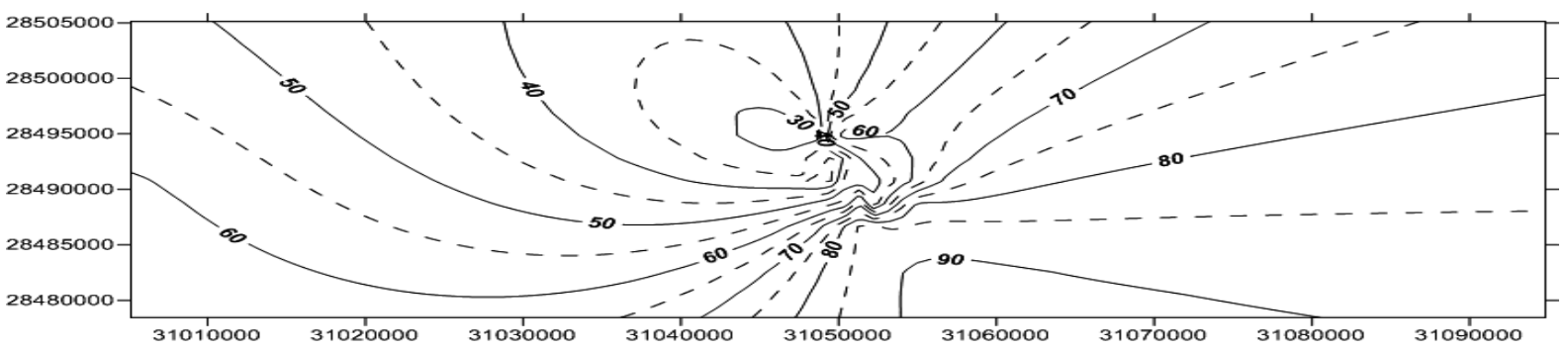

Fig. (4): Contour map showing ${ }^{238} \mathrm{U}\left({ }^{234} \mathrm{Th}\right)$ distribution of the studied A-Dabaa site.

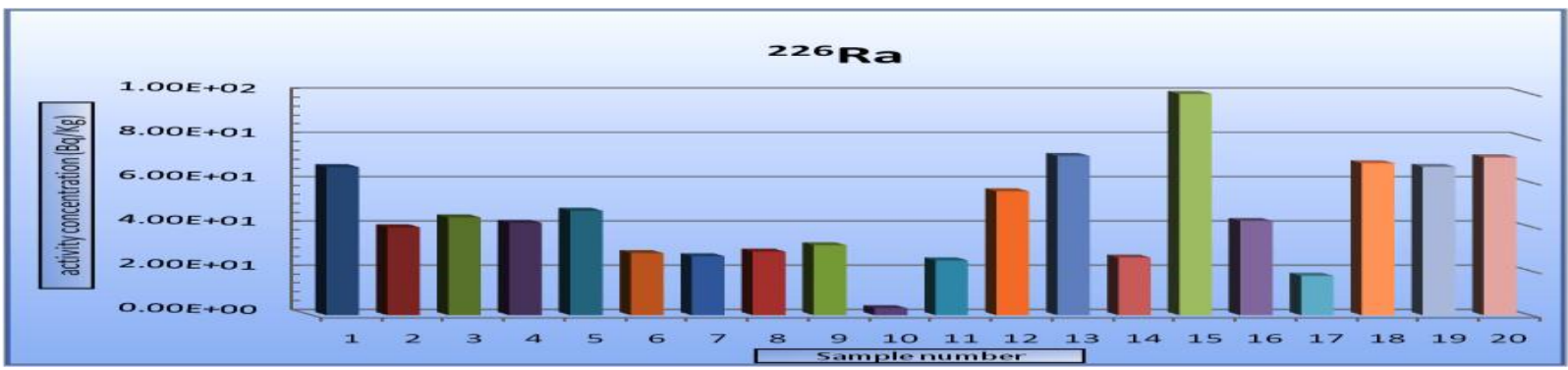

Fig. (5): The measured ${ }^{226}$ Ralevels in the investigated site samples.

The highest ${ }^{226} \mathrm{Ra}$ activity was also found in the location No. 15 of $\sim 99.87 \mathrm{~Bq} / \mathrm{kg}$ (Fig.5). While, the world average limit is $35 \mathrm{~Bq} / \mathrm{kg}(\mathbf{1 1})$. This site is of major Dolomite texture mineralogy.

The 3D correlation between the activity levels of ${ }^{235} \mathrm{U},{ }^{238} \mathrm{U}$ and ${ }^{226} \mathrm{Ra}$ radionuclides for the collected samples site is given in Fig. 6 .

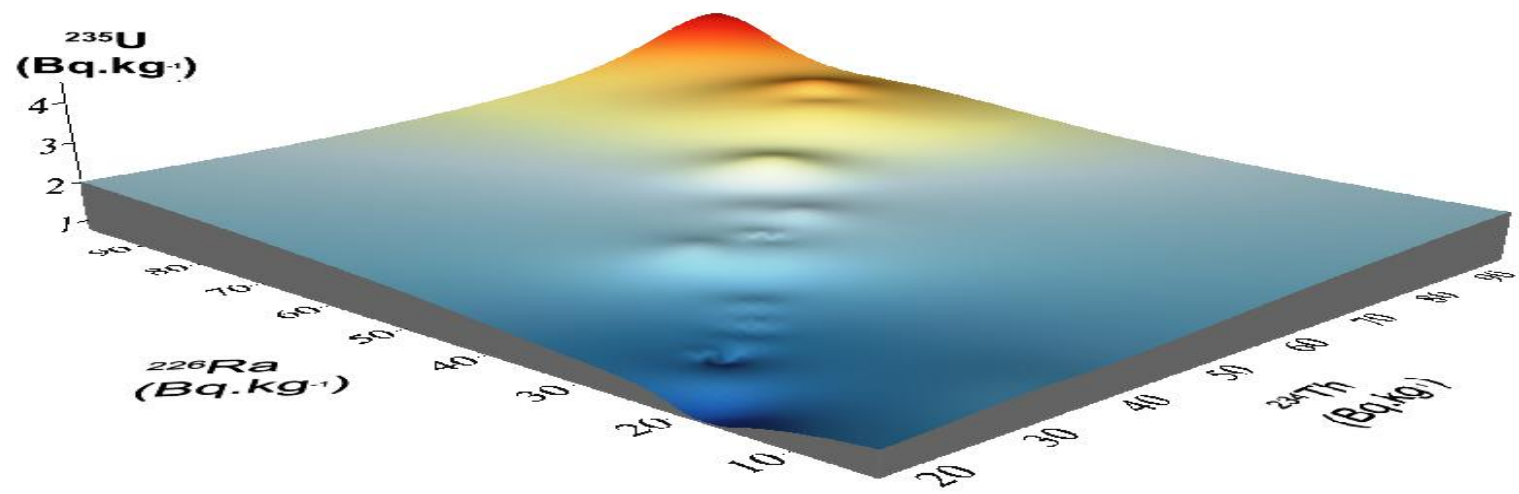

Fig.(6): 3D Correlation between ${ }^{235} \mathrm{U},{ }^{238} \mathrm{U}$ and ${ }^{226}$ Ra specific activity levels of the site.

The highest measured value (site No.5) of ${ }^{232}$ Thwas found to be of specific activity; $7.02 \mathrm{~Bq} / \mathrm{kg}$. The average world value is $30 \mathrm{~Bq} / \mathrm{kg}(\mathbf{1 1})$. This is also belonging to its mineral composition.

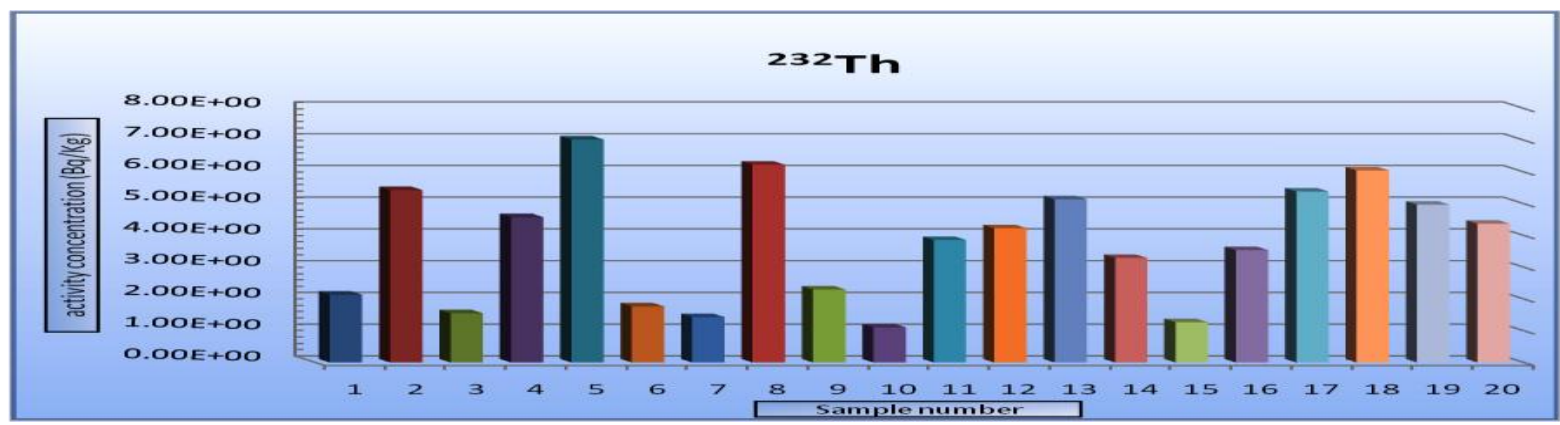

Fig.(7): The measured ${ }^{232}$ Thactivity levels in the site samples. 
It was also observed that the highest ${ }^{40} \mathrm{~K}$ activity is $213 \mathrm{~Bq} / \mathrm{kg}$ (fig.8). The world average is $400 \mathrm{~Bq} / \mathrm{kg}(11$ ).

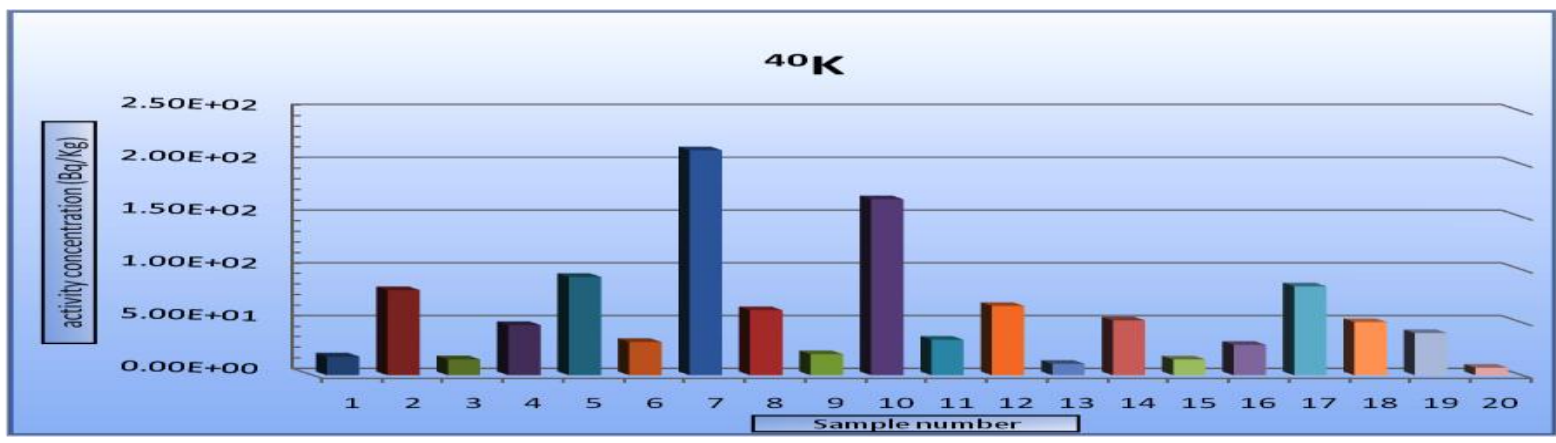

Fig.(8): The measured ${ }^{40} \mathrm{~K}$ activity levels in the site samples.

The 3D correlation between the natural ${ }^{232} \mathrm{Th},{ }^{226} \mathrm{Ra}$ and ${ }^{40} \mathrm{Kspecific}$ activity levels is depicted and given in Fig.9.

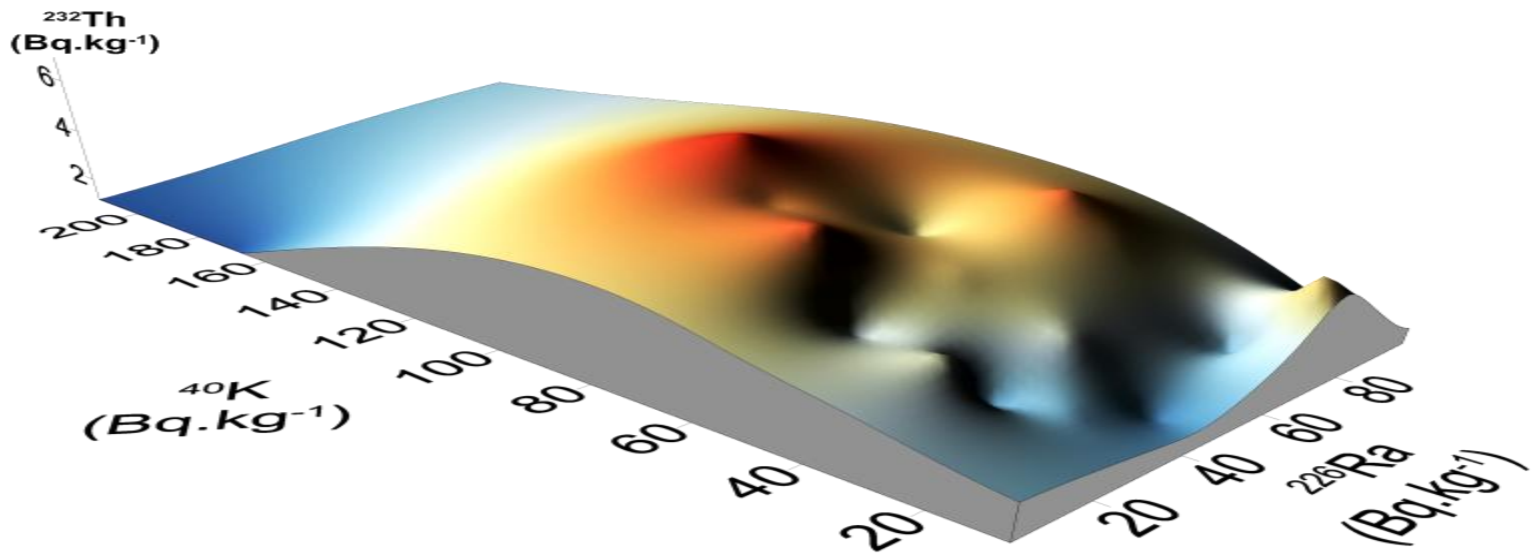

Fig. (9):3DCorrelation between ${ }^{232} \mathrm{Th},{ }^{40} \mathrm{~K}$ and ${ }^{226}$ Ra specific activity of Al-Dabaa site.

The highest calculated absorbed dose rate was also found for location 15 with 47nGy/h(Fig.10). This value is below the average world value $59 \mathrm{nGy} / \mathrm{h}(\mathbf{1 1})$.

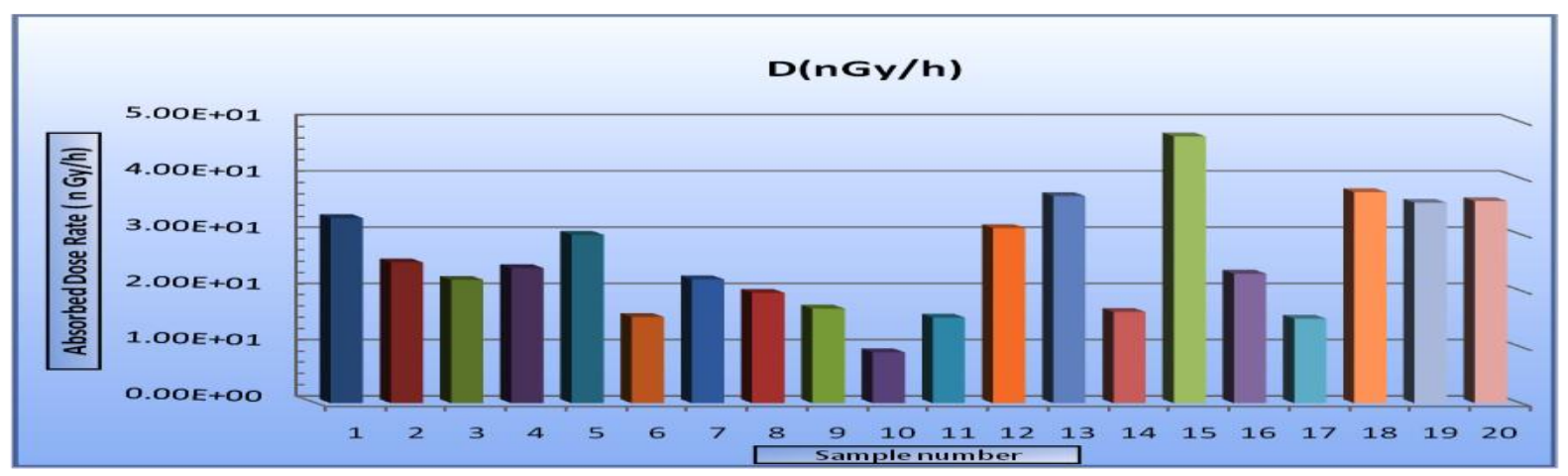

Fig.(10): The calculated absorbed dose rate for the site samples.

The ${ }^{235} \mathrm{U} /{ }^{238} \mathrm{U}$ activity ratio was calculated and found to be in the range from 0.040 to 0.049 and around the normalnatural activityratioof uranium isotopes; 0.046.The results are depicted in(fig.11). 


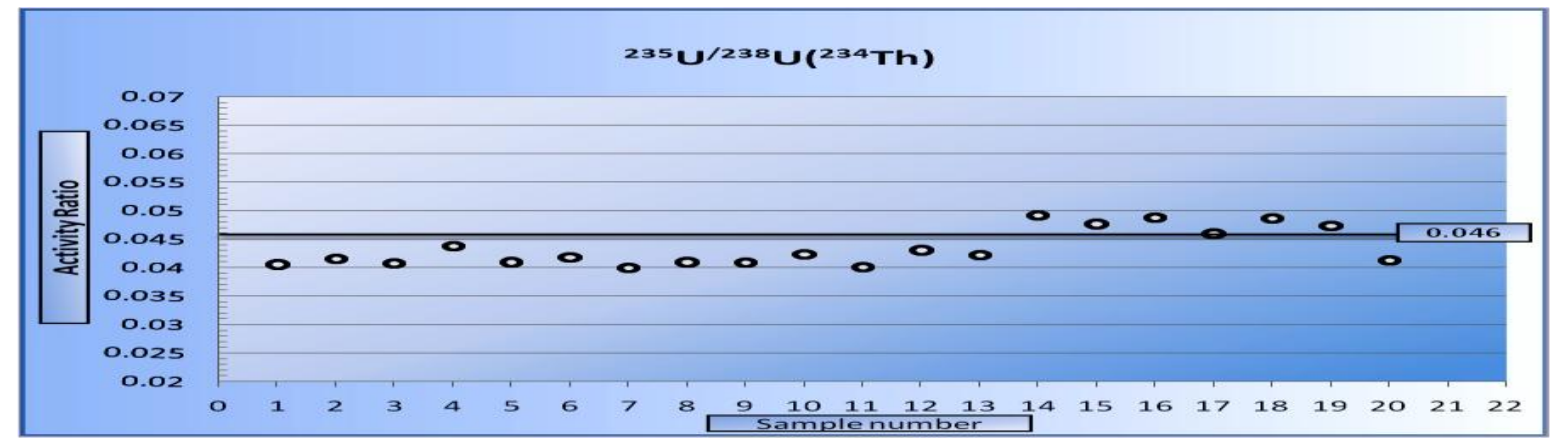

Fig.(11): The calculated ${ }^{235} \mathrm{U} /{ }^{238} \mathrm{U}$ activity ratios of the investigated site.

The man-made ${ }^{137} \mathrm{Cs}$ was found in ultra-low level with maximum activity of $0.191 \mathrm{~Bq} / \mathrm{kg}$ (Fig.12). The presence of this artificial isotope at this depth might be attributed to its penetration by the heavy rain of Al-Dabaa site during the successive winter seasons.

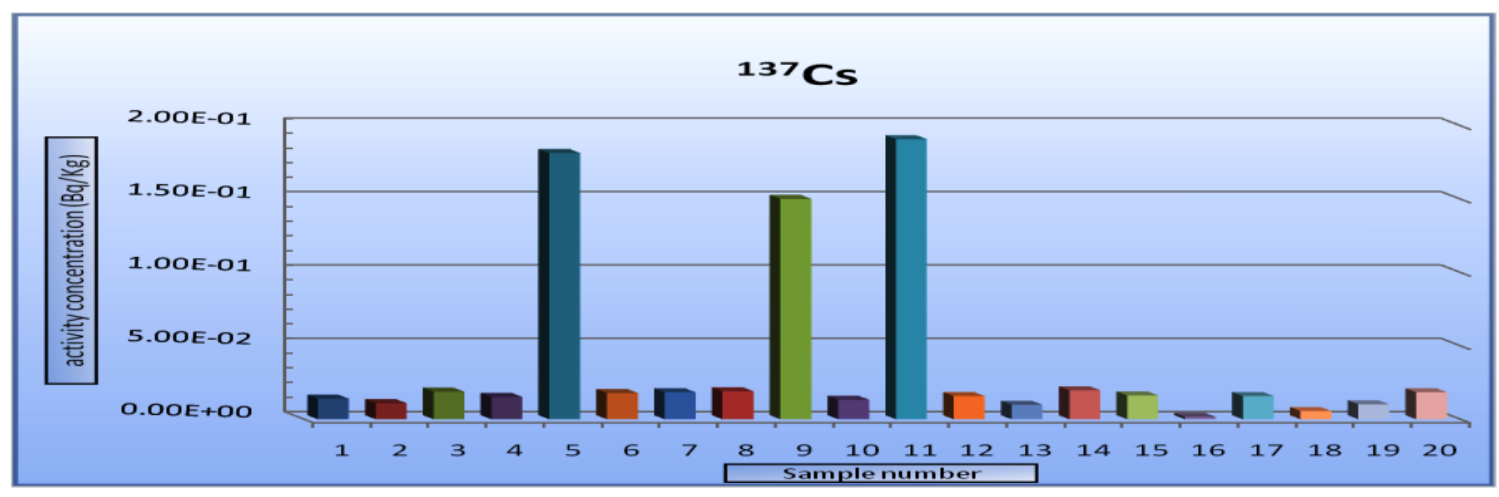

Fig.(12): The measured ${ }^{137} \mathrm{Cs}$ activity levels in the site samples.

Recent study carried out on Al-Dabaa site shows that the levels of natural radioactivity in top surface layer of soil are in average; $122.12 \mathrm{~Bq} / \mathrm{kg}$ for ${ }^{226} \mathrm{Ra}, 10.01 \mathrm{~Bq} / \mathrm{kg}$ for ${ }^{232} \mathrm{Th}$ and $180.04 \mathrm{~Bq} / \mathrm{kg}$ for ${ }^{49} \mathrm{~K}(\mathbf{1 3})$. They found also that the average absorbed dose rateis $24 \mathrm{nGy} / \mathrm{h}$; lower than the world limit.

All the collected samples were investigated by XRD technique for identification of the samples major mineralogical composition. One of the XRD spectrum analyses of Dolomite mineral structure is given in (Fig. 13).

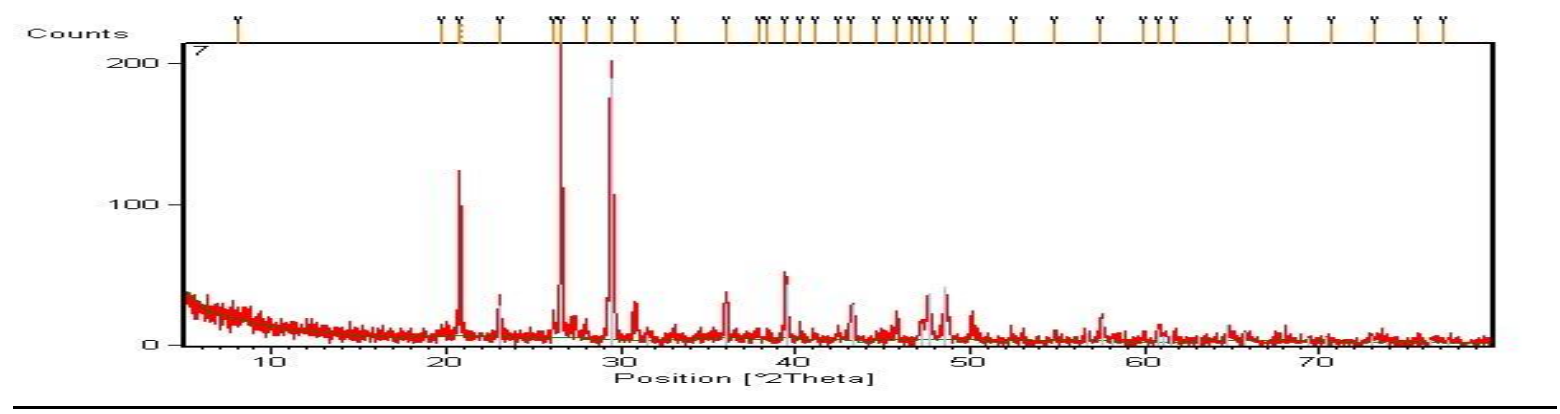

Fig. (13): Spectrum of XRD analysis showing the characteristics Dolomite peaks.

It was observed that the major crystal structure of the site samples texture is Dolomite and Calcite. The results of the site samples mineralogy as obtained by XRD are given in Table (3). 
Table (3) : The XRD Mineralogical structure analysis of Al-Dabaa Site Samples.

\begin{tabular}{|c|c|}
\hline Samples & XRD Mineralogy (\&Chemical Composition) \\
\hline 1 & Ankerite: $\left(\mathrm{Ca}(\mathrm{Fe}, \mathrm{Mg}, \mathrm{Mn})\left(\mathrm{CO}_{3}\right)_{2}\right)$ \\
\hline 2 & Calcite: $\left(\mathrm{CaCO}_{3}\right)$ \\
\hline 3 & Calcite: $\left(\mathrm{CaCO}_{3}\right)$ \\
\hline 4 & Dolomite: $\left(\mathrm{CaMg}\left(\mathrm{CO}_{3}\right)_{2}\right)$ \\
\hline 5 & Dolomite: $\left(\mathrm{CaMg}\left(\mathrm{CO}_{3}\right)_{2}\right)$ \\
\hline 6 & Dolomite: $\left(\mathrm{CaMg}\left(\mathrm{CO}_{3}\right)_{2}\right)$ \\
\hline 7 & Calcium-Carbonate: $\left(\mathrm{CaCO}_{3}\right)$ \\
\hline 8 & Calcium-Carbonate: $\left(\mathrm{CaCO}_{3}\right)$ \\
\hline 9 & Dolomite: $\left(\mathrm{CaMg}\left(\mathrm{CO}_{3}\right)_{2}\right)$ \\
\hline 10 & Dolomite: $\left(\mathrm{CaMg}\left(\mathrm{CO}_{3}\right)_{2}\right)$ \\
\hline 11 & Calcite-Magnesium-syn: (magnesium-rich of calcite) \\
\hline 12 & Dolomite: $\left(\mathrm{CaMg}\left(\mathrm{CO}_{3}\right)_{2}\right)$ \\
\hline 13 & Dolomite: $\left(\mathrm{CaMg}\left(\mathrm{CO}_{3}\right)_{2}\right)$ \\
\hline 14 & Ankerite: $\left(\mathrm{Ca}(\mathrm{Fe}, \mathrm{Mg}, \mathrm{Mn})\left(\mathrm{CO}_{3}\right)_{2}\right)$ \\
\hline 15 & Dolomite: $\left(\mathrm{CaMg}\left(\mathrm{CO}_{3}\right)_{2}\right)$ \\
\hline 16 & Dolomite-ferroan: $\left(\mathrm{CaCO}_{3} \cdot \mathrm{MgCO}_{3} \cdot \mathrm{FeCO}_{3}\right)$ \\
\hline 17 & Quartz \$-Alpha: $\left(\mathrm{SiO}_{2}\right)$ \\
\hline 18 & Hydrogen-Sulfide: $\left(\mathrm{H}_{2} \mathrm{~S}\right)$ \\
\hline 19 & Dolomite: $\left(\mathrm{CaMg}\left(\mathrm{CO}_{3}\right)_{2}\right)$ \\
\hline 20 & Dolomite: $\left(\mathrm{CaMg}\left(\mathrm{CO}_{3}\right)_{2}\right)$ \\
\hline
\end{tabular}

Generally, the NRC established technical requirements for low-level waste disposal sites that include provisions on avoiding natural resources in the area, such as wildlife preserves (14). The site also must be sufficiently isolated from groundwater and surface water and must not be in an area affected by geological activity like volcanoes or earthquakes(14).As IAEA requirements, the disposal facility shall be operated in accordance with the conditions of the license and the relevant regulatory requirements so as to maintain safety during the operational period and in such a manner as to preserve the safety functions assumed in the safety case that are important to safety after closure (4). In the design and operation of disposal facilities subject to agreements on accounting for, and control of, nuclear material, consideration shall be given to ensuring that safety is not compromised by the measures required under the system of accounting for, and control of, nuclear material. For a closed geological disposal facility, IAEA nuclear safeguards might, in practice, 
be applied by remote means (e.g. satellite monitoring, aerial photography, micro-seismic surveillance and administrative arrangements). Intrusive methods, which might compromise safety after closure, have to be avoided (4).

\section{Conclusions}

The results of Al-Dabaa site radiological mapping at low depth profile ( 12 meters) show normal levels of natural ${ }^{232} \mathrm{Th}$ series and ${ }^{40} \mathrm{Kradionuclides}$. While higher levels of ${ }^{238} \mathrm{U}\left({ }^{234} \mathrm{Th}\right)$ and ${ }^{226} \mathrm{Ra}$ than the average world values were observed and measured; $\sim 96 \mathrm{~Bq} / \mathrm{kg}$ and $\sim 99.87 \mathrm{~Bq} / \mathrm{kg}$ respectively. The ${ }^{235} \mathrm{U} /{ }^{238} \mathrm{U}$ ratios show natural origin of the investigated area and within the reference normal value 0.046 . The calculated absorbed dose rates are below the average world range; $59 \mathrm{nGy} / \mathrm{h}$. The artificial $\left({ }^{137} \mathrm{Cs}\right)$ was found to be in very low activity levels; the upper value is $0.191 \mathrm{~Bq} / \mathrm{kg}$. The XRD analysis results show that the major minerals of the site samples are Dolomite and Calcite. In general, the results obtained are of great importance as base-line mapping at low depth profile for construction any potential radioactive waste disposal facility at Al-Dabaa site. They are also considered as input data for code modeling calculations of potential radionuclides releases and their migration into the geosphere and/or biosphere within the site.

\section{ACKNOWLEDGMENT}

The authors are indebted to the supervisor and analysts of the main radiation laboratories of the Egyptian armed forces for their sincere help and cooperation.

\section{REFERENCES}

[1]Neil A. Chapman."Natural radioactivity and radioactive waste disposal", Journal of Volcanology and geothermal research, 50.1-2 (1992): 197-206.

[2] POINSSOT, Christophe; GECKEIS, Horst. Overview of radionuclide behavior in the natural environment. In: Radionuclide Behaviour in the Natural Environment. 2012. p. 1-10.

[3] UM, Wooyong; SERNE, R. Jeffrey. Sorption and transport behavior of radionuclides in the proposed lowlevel radioactive waste disposal facility at the Hanford site, Washington.Radiochimica Acta, 2005, 93.1: 57-63.

[4] IAEA Safety standard, Disposal of Radioactive waste, No. SSR. 5,2011.

[5]ConsejodeSeguridadNuclear. MinisteriodeIndustria,TurismoyComerciodeEspaña,ed. "Radiaciónnaturaly artificial" (in Spanish).Retrieved 24 February 2016.

[6] Varskog, P; Stralberg, E; Varskog, A.T.S; Raaum, A. Naturally occurring radionuclides in the marine environment: an overview of current knowledge with emphasis on the North Sea area. Kjeller: Norse Decom AS. p.7. ISBN 82-92538-01-1. (2003).

[7]Idaho State University (ed.). "Radioactivity in Nature". Retrieved,25 February 2016.

[8] IAEA Safety Standards Classification of Radioactive Waste, No. GSG-1, 2009

[9] Paul J Schields, 'Bragg's Law and Diffraction: How Waves Reveal the Atomic Structure of Crystals', Center for High Pressure Research, State University of New York at Stony Brook (2004).

[10] ABDEL-RAHMAN, Mohamed AE; EL-MONGY, Sayed A. Analysis of radioactivity levels and hazard assessment of black sand samples from Rashid area, Egypt. Nuclear Engineering and Technology, 2017, 49.8: 1752-1757. 
[11] United Nations. Scientific Committee on the Effects of Atomic Radiation. (2008). Report of the United Nations Scientific Committee on the Effects of Atomic Radiation: Fifty-sixth Session (10-18 July 2008) (No. 46). United Nations Publications.

[12] LILLEY, John. Nuclear physics: principles and applications. John Wiley \& Sons, 2013.

[13] EL-DALY, T. A.; HUSSEIN, A. S. Natural radioactivity levels in environmental samples in north western desert of Egypt. In: Proceedings of the 3rd environmental physics conference. 2008. p.19-3. [14] Nuclear Energy Institute (NEI), "Disposal of commercial low-level",2014

https://www.nei.org/.../Disposal-Of-Commercial-Low-Level-Radioactivewaste. 